\begin{abstract}
The primary oil processing product is a mixture of different hydrocarbons. One of the hard-to-process petroleum products is fuel oil. This paper considers a method to derive clear (light) fractions of petroleum products by the catalytic processing of fuel oil on a zeolite-containing catalyst at $1 \mathrm{~atm}$ under the technological conditions of aerosol nanocatalysis. The prospect of the catalytic processing of a viscous residue - fuel oil - has been analyzed and estimated. The process is carried out by dispersing the catalytically active component in a vibratory-fluidized layer. Chemical transformation occurs during the constant mechanochemical activation of catalyst particles by forming an aerosol cloud in the reactive volume. Natural zeolite catalyst of the type $Y$ was selected for research. Methods for separating the gasoline and diesel fractions of light hydrocarbons and for analyzing the gas phase have been given. The effect of the concentration of zeolite catalyst aerosol on the composition of cracking products (the yield of the gasoline and diesel fractions of light hydrocarbons) has been studied. It is noted that the rate of the course of fuel oil processing in the aerosol of the catalyst is 1.5-2 times higher than that in thermal processing. It has been found that in fuel oil processing based on the aerosol nanocatalysis technology, the concentration of the catalyst can be controlled to produce the final product. The study results have shozen that the optimal conditions for processing fuel oil in the aerosol of the catalyst should be considered $773 \mathrm{~K}$, a frequency of $5 \mathrm{~Hz}$, a pressure of $1 \mathrm{~atm}$. At the same time, a concentration of the catalyst of 1-5 $\mathrm{g} / \mathrm{m}^{3}$ should be considered optimal for the output of a light fraction of hydrocarbons. In this case, the yield is up to $80 \%$ of the fraction in the laboratory. It was found out that during the processing of fuel oil, the concentration of the catalyst makes it possible to optimize the output of light oil products under the technological conditions of aerosol nanocatalysis

Keywords: aerosol nanocatalysis, fuel oil processing, vibration fluidization, zeolite catalyst, light hydrocarbon fraction, mechanochemical activation
\end{abstract}

UDC 665.637 .5

DOI: $10.15587 / 1729-4061.2021 .224228$

\section{REVEALING THE EFFECT OF CATALYST CONCENTRATION ON THE PROCESS OF FUEL OIL REFINING USING THE TECHNOLOGY OF AEROSOL NANO CATALYSIS}

\author{
S. Le on e n ko \\ Department of Public Administration, \\ Management and Marketing** \\ E-mail: leonenko.2307@gmail.com \\ S. Kudryavt se v \\ PhD, Associate Professor* \\ E-mail: sergeykudryavtsevsnu@gmail.com \\ I. G I ik in a \\ Doctor of Technical Sciences, Professor* \\ E-mail: irenne5555@ukr.net \\ V. Tarasov \\ $\mathrm{PhD}$, Associate Professor \\ Department of Mining** \\ E-mail: tarasov@snu.edu.ua \\ O. Zolotarova \\ $\mathrm{PhD}$, Associate Professor* \\ E-mail: 22helen72@gmail.com \\ *Department of Chemical Engineering and Ecology** \\ **Volodymyr Dahl East Ukrainian National University \\ Tsentralnyi ave., 59-a, Severodonetsk, Ukraine, 93400
}

\section{Introduction}

There was a steady increase in oil refining volumes between 2000 and 2005 [1]. The depth of oil refining in 2007 in the industry remained low - $73 \%$ [2]. Ukraine's oil and gas industry development strategy to 2035 calls for a structure that could ensure the production of all basic petroleum products with a $75 \%$ oil refining depth [3]. This is well below the global level [4]. The depth of oil refining at refineries in the United States reaches $90 \%$, Japan - almost $96 \%$, which is close to the theoretically possible value. Refineries in Europe have an oil refining depth exceeding $85 \%$. Such high indicators are achieved through the processes of catalytic cracking and hydrocracking of vacuum gas oil, fuel oils, and heavy oil residues.

Since the 2000 s, it has been known that many oil secondary processing techniques have been in place to increase the depth of oil refining [5]. One of the main secondary processing techniques is catalytic cracking. The process is carried out in elevator reactors using microspherical aluminosilicate catalysts. The installation for catalytic cracking (CC) of vacuum gasoil has been operating at the Lysychansk refinery since 2004 .

Oil refining techniques also include the process of hydrocracking (HC).

Among the known techniques for the secondary processing of heavy oil fractions (fuel oil) is the process of visbreaking. This is the process for deriving boiler fuels from tar. In the absence of a visbreaking unit to produce commercial fuel oil, most of the gasoil is used as a diluent to ensure its viscosity characteristics. This process makes it possible to utilize gas-oil fractions sparingly, as well as to obtain commercial fuel oil (tar) of lower viscosity, as well as additional volumes of vacuum gas oil. Thus, a given process of oil refining contributes to increasing the depth of its processing at refineries. That reduces the production of fuel oil and increases the production of vacuum gas oil [7].

Industrial processing of heavy oil raw materials (fuel oil) is practically non-existent. The reason is the complexity of thermal and even catalytic conversion of fuel oil. Most refineries have a weighted oil residue sent to the production of tar and bitumen. However, this residue also contains 
fractions of light oil products, which are impossible to isolate by existing methods.

Note that the development of the refining industry in Ukraine is experiencing some difficulties, the main ones include:

- the wear of the equipment, which is about $80 \%$ for most technological units;

- a low oil refining depth;

- the difficulty to meet the requirements for motor fuels (environmental and operational) compared to European ones.

The processing of heavy raw materials such as fuel oil can be considered a promising secondary processing technique. The result is a fraction of light hydrocarbons and the residue of fuel oil. A given residue can presumably be used, for example, in the production of bitumen and asphalt. Catalytic processing of oil raw materials is constantly of interest to researchers. Research into the processing of fuel oil has not advanced much recently even though the processing technique is promising. One of the factors of catalytic transformations is the catalyst, namely its composition, concentration, structure. Studies on this issue could answer questions about the possibility of processing heavy raw materials such as fuel oil in a catalyst aerosol and would make it possible to manage the concentration of the catalyst to produce light hydrocarbons.

In Ukraine, the catalytic cracking unit G-43-107 M/1 for vacuum gas-oil with a capacity of 2 million tons per year for raw materials was successfully operated at the Lysychansk refinery until 2012. The operation of the unit provided a depth of oil processing of $76 \%$, as well as the output of gasoline fractions with an octane number of $80-82$. The unit was based on modern technology; an elevator reactor and microspherical zeolite-containing catalyst were used. This makes it possible to achieve high rates of chemical cracking reactions and good yields of targeted products. However, a given process faces a series of difficulties contributing to finding the relevant scientific tasks, namely:

- the stricter requirements for the catalyst in terms of its thermal and mechanical stability as the catalyst is in constant motion;

- large dimensions of basic equipment, for example, to produce 2 million tons per year, it is noted that the volume of the reactor is $800 \mathrm{~m}^{3}$, the regenerator $-1,600 \mathrm{~m}^{3}$;

- the impossibility of processing heavy raw materials without a significant renovation of production [8] and altering the norms for the technological regime.

\section{Literature review and problem statement}

Work [6] describes the process of hydrocracking as one of the techniques for oil secondary processing. The process is carried out under the influence of hydrogen at a temperature of $330-450{ }^{\circ} \mathrm{C}$ and a pressure of 5-30 MPa in the presence of nickel-molybdenum catalysts. The disadvantages of a given process include the high pressure and increased explosiveness of the installation.

The process of hydrocracking is used to produce hydrocarbons, which serve as raw materials during their processing by catalytic cracking. The result is the diesel fraction of hydrocarbons [9]. Studying the hydrocracking process shows the following:

- the process occurs at high temperatures and pressure;
- a catalyst of the complex mixed composition is used, where the stage of its preparation is a separate stage of the technological process;

- the technological scheme includes many stages before the products are obtained;

- there is a low conversion yielding the output of certain reaction products [10].

The process of hydrocracking is gradually entering the field of nanotechnology; scientists are developing nanocatalysts. However, studying the process leads to the application of the catalyst of complex composition, the complexity of optimizing the process with a trade-off between the technological and financial components, incomplete or partial conversion reduces the quality of the distillate product [11].

Paper [7] describes the process of oil processing by visbreaking. The process of oil processing is developing but the demand for boiler fuel is constantly decreasing. Clear fractional sections are used to design new installations. This makes it possible to increase the selection of distillates. According to the material balance for the atmospheric piping unit (AP) in a visbreaking plant, it is noted that there is such an average output of products (\% by weight): $\mathrm{C}_{1}-\mathrm{C}_{4}$ fraction $-4 ; \mathrm{C}_{5}$ fraction $\left(195^{\circ} \mathrm{C}\right)-7 ;\left(165-350{ }^{\circ} \mathrm{C}\right)$ fraction- 25 ; boiler fuel (residue) -64 . Despite the positive effect of refining, this process increases the depth of oil refining by only $12 \%$.

The process of visbreaking and the process of hydrocracking are constantly being investigated. Most studies involve the chemical component of the catalyst's effect on the process. Work [12] investigated the cobalt-tungsten catalyst and its effect on the conversion in the process of visbreaking. The authors considered a procedure of preparing the catalyst at mechanical treatment. The main difficulties of the visbreaking process include:

- the complexity of the technological scheme involving many additional stages of preparation;

- the complexity of catalyst preparation technology;

- the difficulty of separating the catalyst from the reaction products.

Study [13] explored the process of visbreaking with obtaining heavy vacuum gasoil for further processing by catalytic cracking, a certain amount of light hydrocarbons, and a vacuum residue for the coking process.

The process of visbreaking is of sufficient interest in the processing of heavy oil raw materials. Two types of technologies are developing: making furnace fuel and obtaining boiler fuel. However, the process of visbreaking has drawbacks: the reverse agitation of the liquid product at a change in the mode, the possibility of depositing coke at the surface of the reaction chamber [14].

Work [15] describes a technique for the catalytic processing of the galvanic industry waste, namely the selection of the catalyst. The starting raw material has a complex composition as it contains metals and salts of inorganic and organic substances. Based on the composition of the raw materials, the porous catalyst used is rapidly deactivated; a constant recovery of the catalyst activity is needed. Sometimes the reduction is used in several stages.

Our analysis of the literary data reveals that the process of visbreaking is promising enough. The prospect is to process heavy oil fractions, namely the search for new catalysts and obtaining the light fractions of hydrocarbons. This area is of a research nature; such processing is practically not carried out at an industrial scale. Most refineries are limited to secondary distillation with a fraction of light hydrocarbons, 
which is $50 \%$, and the rest is fuel oil. For existing technologies, such processing is a complicated process, which is why the oil is sent to the production of bitumen.

The process of oil refining is a promising scientific direction. The constant interest in oil refining leads to the search for new alternative high-efficiency technologies for processing even heavy-weighted raw materials $[16,17]$. As a result of the search, the choice focused on the new evolving technology of aerosol nanocatalysis. The technology has already proven successful in the processes of catalytic cracking of vacuum gasoil on zeolite catalysts [18]. In this regard, it should be noted that the complex physical and chemical characteristics of raw materials do not make it possible to use conventional catalytic systems in the process of fuel oil refining to a fraction of light hydrocarbons. Resolving this issue could allow the refineries to carry out the secondary processing of all oil products, even residual heavy fractions. Therefore, relevant studies aimed at finding possibilities for the complete separation of fractions of light hydrocarbons from fuel oil could solve the task related to the full utilization of heavier residue.

\section{The aim and objectives of the study}

The aim of this work is to identify the effect of catalyst concentration on the process of the thermocatalytic cracking of fuel oil applying the AnCVB technology. That could allow the refineries to carry out the secondary processing of all oil products, even residual heavy fractions.

To accomplish the aim, the following tasks have been set:

- to prove the catalytic effect of the Y-type zeolite involving the AnCVB technology in the process of fuel oil thermocatalytic cracking;

- to investigate the dependence of reaction rate and the yield of individual products on the catalyst concentration;

- to compare the effect of catalyst concentration with the effect of mechanical and chemical activation intensity on the rate of reactions and the yield of products and determine the effect of AnCVB technology conditions on the selectivity of fuel oil cracking reactions.

\section{Materials and methods to study the process of fuel oil refining}

We studied the process of fuel oil refining at the laboratory installation for aerosol nanocatalysis described in works $[18,19]$. The laboratory installation consists of three basic nodes: a reagent feed node, a reaction node, a reaction product selection node. The catalytic transformation of fuel oil takes place in a vibratory-fluidized layer. The layer is formed and maintained mechanically at the vibration frequency control. A catalytic system is a mixture of dispersed material and catalyst. The raw material is fuel oil - the material flow from the cube of the vacuum column at the $\mathrm{AD} / \mathrm{VD}$ unit of the Lysychansk refinery. The density at $25^{\circ} \mathrm{C}$ is $935 \mathrm{~kg} / \mathrm{m}^{3}$.

The mixture of liquid products from processing was distilled at a laboratory vacuum plant assembled in line with ASTM D86-20b, at a pressure of $2 \mathrm{kPa}$ and a temperature of up to $350{ }^{\circ} \mathrm{C}$. In this case, a wide fraction was obtained, which corresponds to the boiling point at atmospheric pressure. Next, the received fraction was distilled at the device ULAB-1-42A, where a fraction with a temperature of $35-180^{\circ} \mathrm{C}$ (petrol fraction) and a diesel frac- tion $\left(t_{\text {boil }}=180-350^{\circ} \mathrm{C}\right)$ is isolated. This is the interval of the temperature of the onset and end of fraction boiling. The heavy residue was determined at the first stage of distillation $\left(t_{\text {boil }}>350{ }^{\circ} \mathrm{C}\right)$.

The gas-phase was analyzed at the Kristal-200, Tsvet-500, and LHM-8 chromatographers.

The process of fuel oil refining was studied using the zeolite-containing catalyst (the Y-type), which proved effective for catalytic cracking processes. A catalyst is a zeolite without prior treatment and preparation. The activation of the catalyst occurs mechanically. The original size of the catalyst particles is $100-200 \mu \mathrm{m}$.

\section{Experimental study of the process of fuel oil thermocatalytic cracking}

\section{1. The catalytic effect of the catalyst aerosol}

Experiments that are summarized in Table 1 were conducted to prove the catalytic effect of the Y-type zeolite using the AnCVB technology. The study models the thermal process in an empty reactor (Table 1, line 1); the process in a reactor filled with dispersed material (Table 1, line 2); the process in a reactor with dispersed material in the presence of mechanical and chemical activation but without a catalyst (Table 1, line 3). The resulting values of the degree of conversion of raw materials $\mathrm{X}$, product outputs, the selectivity of light products formation $\phi_{L P}$, and reaction rate $r_{1}, r_{2}$ were compared with the data from the experiment involving mechanical and chemical activation whose intensity coincides with the data from line 3 , and the free catalyst in the reaction zone - lines $6,8-16$, Table 1.

The comparison of the composition of products revealed that increased coking was observed under the conditions of thermal cracking (lines 1-3, Table 1). The yield of coke was so significant that it hindered the process for a long time - after 15-25 minutes of a continuous feed of the raw materials there was an avalanche-like build-up of solid products; the process had to be stopped for the regeneration of the internal space of the reactor. The overall degree of fuel oil conversion, in this case, did not exceed $46.5 \%$ by weight. The application of mechanical and chemical activation to the dispersed material in the absence of a free catalyst even reduced the degree of conversion to $44.3 \%$ (line 3 , Table 1 ). That may be due to the intensification of agitation in the reaction zone and that the reactor approached the mode of mixing, where, all other things being equal, the overall degree of conversion is always less than that in a unit operated under a regime close to displacement. The addition of a free catalyst to the reactor in the amount, which ensures its concentration in the reaction volume at $1 \mathrm{~g} / \mathrm{m}^{3}$ (line 8 , Table 1 ), increased the overall degree of conversion $(X)$ to $60.2 \%$. The composition of cracking products also changed: the amount of solid products decreased to $0.3 \%$, which made it possible to carry out the process without regenerating the catalyst for 4 hours, or longer, thereby maintaining the high outputs of targeted products. The selectivity of light product formation (all liquid products boiling to $623 \mathrm{~K}$ ) for the AnCVB conditions increased from $82.4 \%$ to $92.5 \%$ (the comparison of lines 3 and 8 , Table 1). Thus, the application of AnCVB technology to the process of fuel oil cracking could increase the degree of conversion of the raw material by 1.4-1.9 times, reduce the rate of coke accumulation in the reactor, decrease its yield from 4.3 to $0.3 \%$, increase the selectivity of light product formation by 1.12 times. 
Table 1

Results of the experimental study into the process of thermocatalytic cracking of fuel oil using the AnCVB technology (a temperature in the reactor of $773 \mathrm{~K}$, the consumption of raw materials is $0.064 \mathrm{~kg} / \mathrm{h}$, the reactor's volume is $38 \mathrm{ml}$, the share of the dispersed material is $50 \%$ of reactor volume)

\begin{tabular}{|c|c|c|c|c|c|c|c|c|c|c|}
\hline \multirow[b]{2}{*}{ No. } & \multirow[b]{2}{*}{$\mathrm{Hz}$} & \multirow{2}{*}{$C_{\text {catalyst }}, \frac{\mathrm{kg}}{\mathrm{m}_{\text {reactor }}^{3}}$} & \multicolumn{4}{|c|}{ Yield of derived fraction, $\%$ by weight } & \multirow[b]{2}{*}{$X, \%$} & \multirow[b]{2}{*}{$\phi_{L P}$} & \multirow{2}{*}{$r_{1}, \frac{\mathrm{kg}}{\mathrm{m}_{\text {reactor }}^{3} \cdot \text { hour }}$} & \multirow{2}{*}{$r_{2}, \frac{\mathrm{kg}}{\mathrm{kg}_{\text {catalyst }} \cdot \text { hour }}$} \\
\hline & & & $\begin{array}{l}\text { Gaseous } \\
\text { products }\end{array}$ & $\begin{array}{c}\text { boiling } \\
\text { point }-180^{\circ} \mathrm{C}\end{array}$ & $\begin{array}{c}180- \\
350^{\circ} \mathrm{C}\end{array}$ & coke & & & & \\
\hline 1 & - & 0 & 3.5 & 4.7 & 34.2 & 4.1 & 46.5 & 83.7 & 778 & - \\
\hline 2 & - & 0 & 3.1 & 4.5 & 33.5 & 4.2 & 45.3 & 83.9 & 758 & - \\
\hline 3 & 5 & 0 & 3.5 & 4.8 & 31.7 & 4.3 & 44.3 & 82.4 & 742 & - \\
\hline 4 & 3 & 2 & 4.5 & 0.0 & 61.3 & 0.3 & 66.0 & 92.8 & 1,106 & 552,755 \\
\hline 5 & 4 & 2 & 10.9 & 10.2 & 66.1 & 0.4 & 87.7 & 87.1 & 1,467 & 733,714 \\
\hline 6 & 5 & 2 & 2.1 & 9.0 & 76.0 & 0.3 & 87.4 & 97.3 & 1,463 & 731,371 \\
\hline 7 & 6 & 2 & 2.3 & 6.2 & 60.0 & 0.5 & 69.0 & 95.9 & 1,156 & 577,781 \\
\hline 8 & 5 & 1 & 4.2 & 14.4 & 41.3 & 0.3 & 60.2 & 92.5 & 1,008 & $1,008,250$ \\
\hline 9 & 5 & 5 & 5.7 & 7.0 & 46.2 & 0.2 & 59.1 & 90.0 & 989 & 197,867 \\
\hline 10 & 5 & 10 & 5.4 & 4.2 & 51.6 & 0.3 & 61.5 & 90.7 & 1,030 & 103,018 \\
\hline 11 & 5 & 16 & 5.4 & 3.8 & 53.4 & 0.3 & 62.8 & 91.0 & 1,051 & 65,705 \\
\hline 12 & 5 & 22 & 5.4 & 3.3 & 50.0 & 0.3 & 59.0 & 90.3 & 988 & 44,894 \\
\hline 13 & 5 & 28 & 5.3 & 6.5 & 47.2 & 0.4 & 59.4 & 90.4 & 995 & 35,537 \\
\hline 14 & 5 & 32 & 5.0 & 7.7 & 46.0 & 0.5 & 59.3 & 90.7 & 993 & 31,016 \\
\hline 15 & 5 & 100 & 5.2 & 5 & 30.5 & 3.7 & 44.4 & 79.95 & 743 & 7,433 \\
\hline 16 & 5 & 200 & 4.7 & 4.7 & 31.3 & 4.1 & 44.8 & 80.36 & 750 & 3,750 \\
\hline
\end{tabular}

5. 2. Establishing the dependence of the reaction rate and the yield of individual products on the catalyst concentration

To determine the effect of the catalyst concentration on the reaction rate, the values of specific cracking speeds $r_{1}, \frac{\mathrm{kg}}{\mathrm{m}_{\text {reactor }}^{3} \cdot \text { hour }}$ and $r_{2}, \frac{\mathrm{kg}}{\mathrm{kg}_{\text {catalyst }} \cdot \text { hour }}$ were calculated from equations (1) and (2).

$$
r_{1}=\frac{G_{R M} \cdot X}{V_{\text {reactor }}},
$$

$G_{R M}$ is the raw material consumption, $\mathrm{kg} / \mathrm{h}$; $V_{\text {reactror }}$ is the reactor's volume, $\mathrm{m}^{3}$.

$$
r_{2}=\frac{r_{1}}{C_{\text {catalyst }}}
$$

$C_{\text {catalyst }}$ is the catalyst concentration, $\mathrm{kg} / \mathrm{m}^{3}$.

Our data are visualized to determine the nature of the dependence, Fig. 1, 2.

The effective progress of fuel oil cracking reaction using $\mathrm{AnCVB}$ is ensured at the concentration of a free catalyst at the level of $1 \mathrm{~g} / \mathrm{m}^{3}$ of the reactor. In this case, the reaction rate using $A n C V B$ depends on the concentration of the catalyst: for the given conditions, the optimal is the concentration of the catalyst in the range between 1 and $4 \mathrm{~g} / \mathrm{m}^{3}$ of the reactor, at which the maximum speed $r_{1}$ is observed. Further increase leads to a decrease in speed, and at the concentrations of a free catalyst above $100 \mathrm{~g} / \mathrm{m}^{3}$ (not pictured) the speed is only slightly higher than the values of the thermal process. Thus, the implementation of AnCVB conditions is possible only at the low concentrations of the catalyst aerosol where its mechanical and chemical activation can be carried out effectively. This is consistent with the AnCVB theory implying that there are the optimal parameters of mechanical and chemical activation (mechanical and chemical activation frequency, catalyst concentration, the geometric dimensions of dispersing material, the physical and chemical characteristics of the catalyst and dispersing material) at which the maximum quasi-stationary concentration of the active catalyst nanoparticles is formed while the rate of their formation is much higher than the rate of relaxation and coagulation to micro sizes whereby the hyperactivity is disrupted.

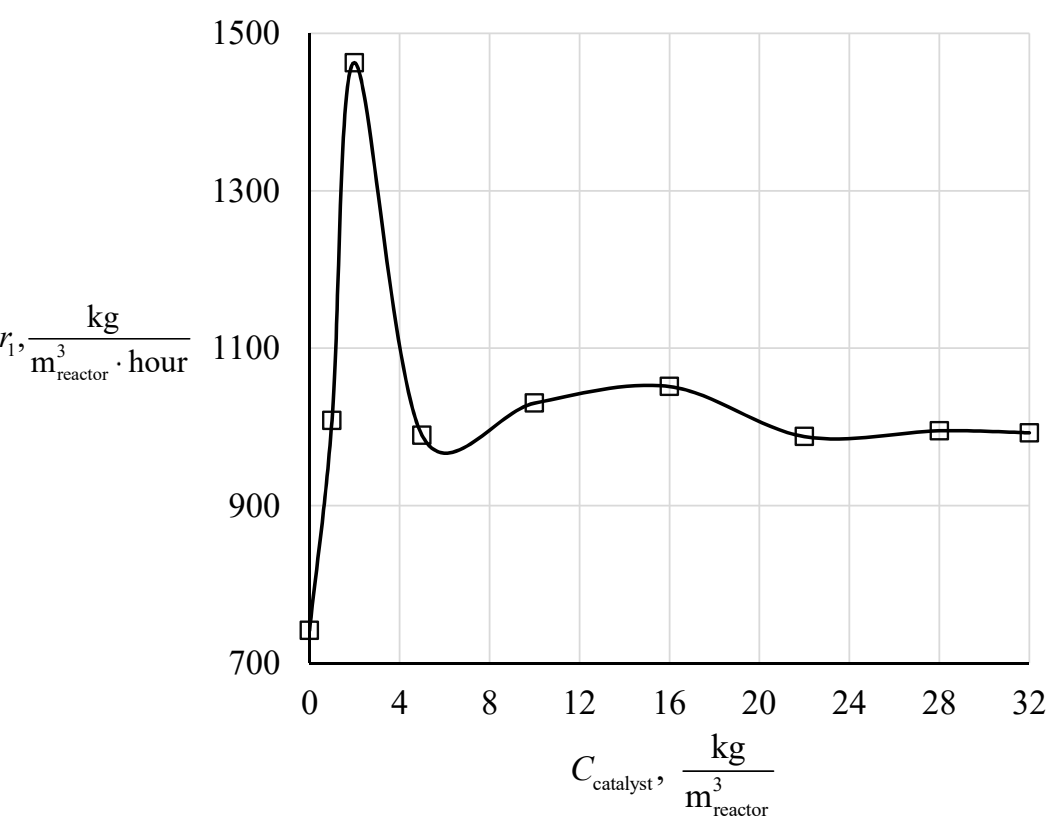

Fig. 1. Change in the specific rate of fuel oil cracking reactions $r_{1}$ using the AnCVB technology dependent on the catalyst concentration ( $T=773 \mathrm{~K}, G_{R M}=0.064 \mathrm{~kg} / \mathrm{h}$, $V_{\text {reactror }}=38 \mathrm{ml}$, the share of dispersing material is $50 \%$ of $V_{\text {reactror }}$ ) 
Fig. 2 shows the effect of concentration on the specific speed $r_{2}$. The nature of the curve is such that the maximum rate is observed at a minimum concentration of the catalyst. In the range of concentrations studied, the optimal concentration appears to be $1 \mathrm{~g} / \mathrm{m}^{3}$ of the reactor. Although there may be a lower concentration at which the AnCVB conditions are formed with the rate $r_{2}$ to be even higher. Because the cost of the catalyst when using the AnCVB technology is ten times lower than that in the conventional heterogeneous catalysis technologies, it is more important to optimize the concentration to maximize the rate $r_{1}$. The rate $r_{2}$, in this case, is such that it depends on $r_{1}$.

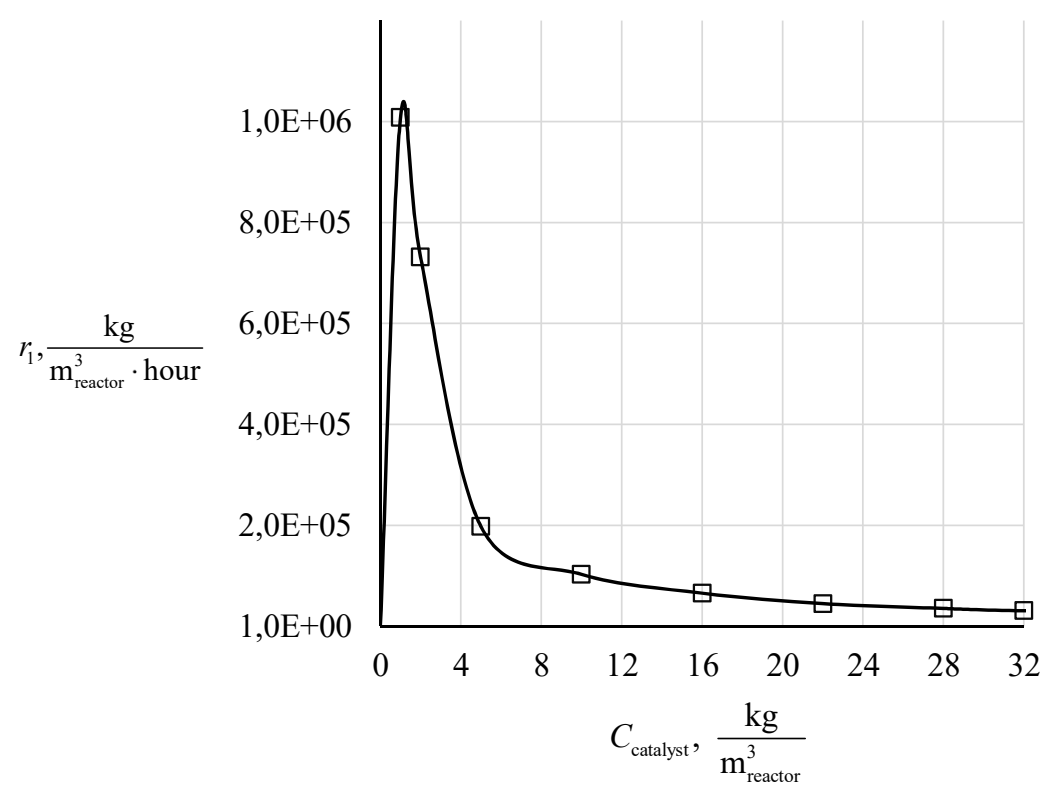

Fig. 2. Change in the specific rate of fuel oil cracking reactions $r_{2}$ when using the AnCVB technology, dependent on the catalyst concentration ( $T=773 \mathrm{~K}$,

$G_{R M}=0.064 \mathrm{~kg} / \mathrm{h}, V_{\text {reactror }}=38 \mathrm{ml}$, the share of dispersing material is $50 \%$ of $V_{\text {reactror }}=$ )

The comparison of product outputs reveals that there are also optimal concentrations of the catalyst at which the maximum output is reached in terms of the total amount of light products or individual fractions.

\section{tion \\ 5. 3. Analysis of the effect of the catalyst concentra-}

To assess the effect of the catalyst concentration on the rate $r_{1}$ and the output of light liquid products, we calculated specific indicators showing the ratio of rate values (3) and the output of the amount of light fractions (4) of the catalytic process under the AnCVB conditions to the values of these indicators in the thermal process. To compare the intensity of the effect of the catalyst concentration with another important control parameter of the AnCVB technology - the mechanical and chemical activation frequency - experiments were carried out at different frequencies (lines 4-7 of Table 1), and a similar comparison calculation was also performed for them. The results of the calculation are given in Table 2 .

$$
\frac{r_{\text {cat }}}{r_{\text {term }}}=\frac{r_{1}}{778}
$$

778 is the value of the rate $r_{1}$ of the thermal process.

$$
\frac{\sum \chi_{L P(c a t)}}{\sum \chi_{L P(\text { term })}}=\frac{\chi_{(35-180)_{i}}+\chi_{(180-350)_{i}}}{\chi_{(35-180)_{\text {term }}}+\chi_{(180-350)_{\text {term }}}}
$$

$\chi_{(35-180)_{i}}, \quad \chi_{(180-350)_{i}}, \chi_{(35-180)_{\text {term }}} \cdot \chi_{(180-350)_{\text {term }}}$ are the outputs of the gasoline $\left(35-180{ }^{\circ} \mathrm{C}\right)$ and diesel fractions $\left(180-350{ }^{\circ} \mathrm{C}\right)$ of the catalytic and thermal processes, respectively.

Our analysis of Tables 2, 3 reveals that the variation in concentration in the study range has a greater impact on the outputs of light products than on the total rate of cracking reactions. The concentration optimization managed to increase the output of the gasoline and diesel fractions by 2.19 times (the best indicator in the examined range), while the rate of the cracking reactions was increased by only 1.88 times. A relatively small increase in speed is due to that the study was conducted at $773 \mathrm{~K}$, which is a significant temperature for the process of cracking at which thermal conversions are already active. The application of the AnCVB technology to the process of the thermocatalytic cracking of fuel oil is advisable primarily because it makes it possible to increase the yield of targeted products.

The variation of the mechanical and chemical activation frequency made it possible to achieve similar indicators of process efficiency, and the general analysis of all the data in the examined range shows that both the concentration of the catalyst and the frequency of mechanical and chemical activation are almost equally able to control the reaction rate and the output of products during the thermocatalytic cracking of fuel oil under the AnCVB conditions.

Because the process of the thermocatalytic cracking of fuel oil is of large-capacity (given its would-be implementation on an industrial scale), the selectivity of the reactions leading to the formation of light products becomes important. Selectivity would directly affect the cost of commercial gasoline and diesel fuels produced on the basis of the gasoline and diesel fractions obtained from a given process. The effect of catalyst concentration on selectivity is shown in Fig. 3.

Table 2

Comparison of the effect of mechanical and chemical activation intensity on the process of the thermocatalytic cracking of fuel oil when using AnCVB technology (a temperature in the reactor is $773 \mathrm{~K}$, the consumption of raw materials is $0.064 \mathrm{~kg} / \mathrm{h}$, the reactor's volume is $38 \mathrm{ml}$, the share of the dispersed material is $50 \%$ of the reactor's volume)

\begin{tabular}{|c|c|c|c|c|c|}
\hline Parameter & \multicolumn{5}{|c|}{ Parameter value } \\
\hline $\begin{array}{c}\text { mechanical and } \\
\text { chemical activa- } \\
\text { tion, Hz }\end{array}$ & 0 & 3 & 4 & 5 & 6 \\
\hline$\frac{r_{\text {cat }}}{r_{\text {term }}}$ & 1.00 & 1.42 & 1.89 & 1.88 & 1.49 \\
\hline$\frac{\sum \chi_{L P(\text { cat })}}{\sum \chi_{L P(\text { term })}}$ & 1.00 & 1.58 & 1.96 & 2.19 & 1.70 \\
\hline
\end{tabular}


Table 3 - at thermal processing, the output of light

Comparison of the effect of catalyst concentration on the process of the thermocatalytic cracking of fuel oil when using AnCVB technology (a temperature in the reactor is $773 \mathrm{~K}$, the consumption of raw materials is $0.064 \mathrm{~kg} / \mathrm{h}$, the reactor's volume is $38 \mathrm{ml}$, the share of the dispersed material is $50 \%$ of the reactor's volume)

\begin{tabular}{|c|c|c|c|c|c|c|c|c|c|c|c|}
\hline Parameter & \multicolumn{10}{|c|}{ Parameter value } \\
\hline$C_{\text {catalyst }} \frac{\mathrm{kg}}{\mathrm{m}_{\text {reactor }}^{3}}$ & 0 & 1 & 2 & 5 & 10 & 16 & 22 & 28 & 32 & 100 & 200 \\
\hline$\frac{r_{\text {cat }}}{r_{\text {term }}}$ & 1.00 & 1.30 & 1.88 & 1.27 & 1.32 & 1.35 & 1.27 & 1.28 & 1.28 & 0.96 & 0.91 \\
\hline$\frac{\sum \chi_{L P(\text { cat })}}{\sum \chi_{L P(t e r m)}}$ & 1.00 & 1.43 & 2.19 & 1.37 & 1.44 & 1.47 & 1.37 & 1.38 & 1.38 & 0.96 & 0.93 \\
\hline
\end{tabular}

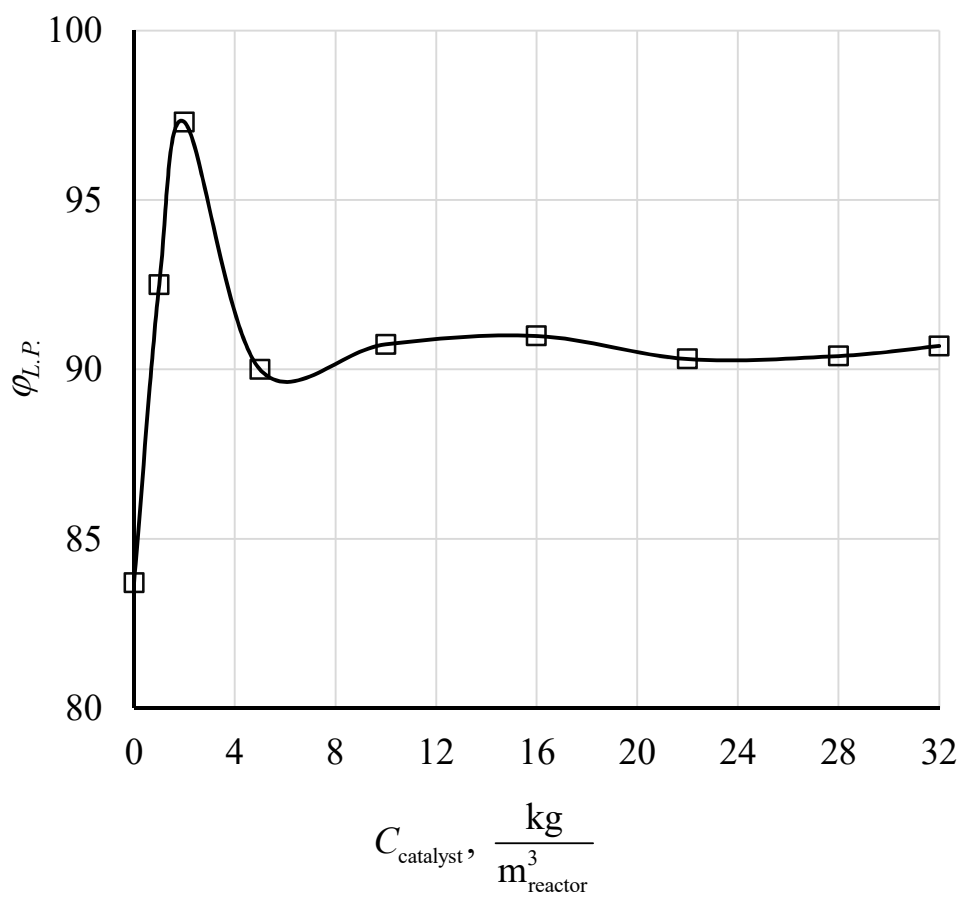

Fig. 3. Change in the selectivity of the reactions of fuel oil cracking when using the AnCVB technology dependent on the concentration of the catalyst ( $T=773 \mathrm{~K}, G_{R M}=0.064 \mathrm{~kg} / \mathrm{h}, V_{\text {reactror }}=38 \mathrm{ml}$, the share of dispersing material is $50 \%$ of $V_{\text {reactror }}$ )

The effect of concentration on selectivity also passes a maximum located in the region between the values of 1 and $4 \mathrm{~g} / \mathrm{m}^{3}$ of the reactor. Further increase in concentration to $32 \mathrm{~g} / \mathrm{m}^{3}$ has little effect on selectivity, and increasing the concentration to $200 \mathrm{~g} / \mathrm{m}^{3}$ (not shown in the chart) reduces selectivity to the values inherent in the thermal process.

\section{Discussion of results of studying the process} of fuel oil refining

When comparing the thermal and catalytic processing of fuel oil, the following is obtained: hydrocarbons is within $50 \%$ by weight;

- at catalytic processing using the AnCVB technology, the light hydrocarbon yield is within $70 \%$ by weight.

It is known that at the actual industrial unit UKM-600 the total output of light fractions is $44 \%$ by weight [8]; at the industrial experimental installation TKM-700-2E, the total output of light fractions is $45 \%$ by weight [20].

It is a well-known fact that nanoparticles are prone to coagulation when colliding in a volume. AnCVB technology resolves this issue through the process of the mechanochemical activation of the catalytic system. That also reduces the impact of the catalyst deactivation process during oil refining.

According to Fig. 1-3, the effect of catalyst concentration passes the optimal value. For the empirical dependences of reaction rates within the volume of the reactor and at the surface of the catalyst on the catalyst concentration, it was decided to divide them into two intervals before and after the optimum. The equations are given below:

$$
\begin{aligned}
& 0<C_{\text {cat }}<2 \mathrm{~g} / \mathrm{m}^{3}, \\
& r_{1}=360.58 \cdot C_{\text {cat }}+710.28
\end{aligned}
$$

(approximation coefficient $R^{2}=0.9779$ ),

$$
\begin{aligned}
& 2<C_{c a t}<32 \mathrm{~g} / \mathrm{m}^{3}, \\
& r_{1}=0.0132 \cdot C_{c a t}^{4}-0.9997 \cdot C_{c a t}^{3}+ \\
& +25.735 \cdot C_{c a t}^{2}-259.99 \cdot C_{c a t}+1850.4
\end{aligned}
$$

(approximation coefficient $R^{2}=0.8847$ ),

$$
\begin{aligned}
& 0<C_{c a t}<1 \mathrm{~g} / \mathrm{m}^{3}, \\
& r_{2}=1 \cdot 10^{6} \cdot C_{c a t}
\end{aligned}
$$

(approximation coefficient $R^{2}=1$ ),

$$
1<C_{\text {cat }}<32 \mathrm{~g} / \mathrm{m}^{3},
$$$$
r_{2}=-172.3 \cdot C_{c a t}^{3}+10,461 \cdot C_{c a t}^{2}-193,030 \cdot C_{c a t}+1 \cdot 10^{6}
$$

(approximation coefficient $R^{2}=0.9402$ ).

Optimal parameters for the catalyst concentration are noted in the interval of $1-5 \mathrm{~g} / \mathrm{m}^{3}$.

With an increase in the catalyst concentration, the output of the gasoline fraction is almost stabilized within $10-32 \%$ by weight. It is estimated that with an increase in the catalyst concentration the rate of the process to form a fraction of light hydrocarbons decreases due to the coagulation of nanoparticles and the growth of coking. The maximum output rate of the light hydrocarbon fraction is noted at a catalyst concentration of $1 \mathrm{~g} / \mathrm{m}^{3}$ within $60 \%$. 
The resulting empirical dependences show that the selected conditions of the process are within the optimal interval to produce a fraction of light hydrocarbons. It is noted that:

- the output of the fraction of light hydrocarbons under the technological conditions of aerosol nanocatalysis is within $60-70 \%$, and the output of the fraction of light hydrocarbons at thermal cracking is within $45 \%$;

- the reaction rate to derive a fraction of light hydrocarbons under the technological conditions of aerosol nanocatalysis in the volume of the reactor is within $1,000 \mathrm{~kg} / \mathrm{m}^{3} \cdot \mathrm{h}$;

- the rate of reaction to derive a fraction of light hydrocarbons under the technological conditions of aerosol nanocatalysis per gram of catalyst is within $10^{6} \mathrm{~kg} / \mathrm{g}_{\text {cat }} \cdot \mathrm{h}$.

Our study has shown a clear dependence on catalyst concentration. It is noted that at the concentration of the catalyst from 1 to $5 \mathrm{~g} / \mathrm{m}^{3}$ fuel oil converts up to $70 \%$ into a fraction of light hydrocarbons. At the concentration of the catalyst from 5 to $20 \mathrm{~g} / \mathrm{m}^{3}$ fuel oil converts up to $60 \%$ into a fraction of light hydrocarbons. At the concentration of the catalyst from $100 \mathrm{~g} / \mathrm{m}^{3}$, fuel oil is converted to $40 \%$ into a fraction of light hydrocarbons.

The results of our study demonstrate the prospect of processing fuel oil under the AnCVB conditions. That could make it possible to convert almost $50 \%$ of the heavy fraction of fuel oil into light hydrocarbons, which are widely used.

\section{Conclusions}

1. The result of the catalytic conversion of fuel oil whereby light hydrocarbons were derived has established that the output increases by 1.5 times compared to the yield during the thermal cracking of fuel oil. The processing of fuel oil using aerosol nanocatalysis technology is promising. That could allow the refinery to implement deep secondary oil processing as it would include the processing not only of vacuum gas oil but also the viscous residue of fuel oil. In this case, one can use the most common natural zeolite catalyst for the processing of petroleum products.

2. It has been found that the catalyst concentration is one of the main parameters to control the process. We have noted the effect of catalyst concentration on the output of light hydrocarbons and the reaction rate of fuel oil conversion. It was established that the optimal concentration of the Y-type zeolite catalyst is the interval of $1-5 \mathrm{~g} / \mathrm{m}^{3}$, with the output of light hydrocarbons up to $80 \%$. In this case, the observed reaction rate of fuel oil conversion into light hydrocarbons is about $1,000 \mathrm{~kg} / \mathrm{m}^{3} \cdot \mathrm{h}$ and about $10^{6} \mathrm{~kg} / \mathrm{g}_{\text {cat }} \cdot \mathrm{h}$. This is because the catalyst contributes not only to the acceleration of chemical conversion but also to the conversion of petroleum products into a fraction of light hydrocarbons. The zeolite catalyst aerosol contributes to the processing of fuel oil into the fractions of light hydrocarbons and reduces the process of coking at a temperature of $773 \mathrm{~K}$.

3 . The analysis of our experimental results reveals that the ratio of the output of light hydrocarbons obtained by the catalytic method to thermal one increases by almost 2 times with an increase in the frequency of vibrations. The ratio of the yield of light hydrocarbons obtained by the catalytic method to thermal one increases by almost 1.5 times with an increase in the catalyst concentration. Similarly, the ratio of the rates of catalytic to thermal conversion increases.

\section{References}

1. Ukraine Energy Information. Interactive Chart Ukraine Refined Oil Products Production (2019). Available at: https://www. enerdata.net/estore/energy-market/ukraine/

2. Oil refining industry of Ukraine (2004-2007) (2008). Available at: http://ukrexport.gov.ua/eng/economy/brief/ukr/188.html

3. Konończuk, W. (2017). The never-ending collapse. The state of the Ukrainian oil sector. Ośrodek Studiów Wschodnich im. Marka Karpia, 44. Available at: https://www.osw.waw.pl/sites/default/files/raport_never-ending_net.pdf

4. Kaiser, M. J. (2017). A review of refinery complexity applications. Petroleum Science, 14 (1), 167-194. doi: https://doi.org/10.1007/ s12182-016-0137-y

5. Dalla Giovanna, F., Khlebinskaia, O., Lodolo, A., Miertus, S. (2003). Compendium of Used Oil Regeneration Technologies. Trieste: UNIDO, 210.

6. Patrylak, L. K., Ionin, V. O., Bartosh, P. I., Likhnyovskyi, R. V. (2003). Comparative properties of the zeolite acid catalysts of different preparation. Kataliz i neftehimiya, 11, 25-28.

7. Ahmetov, S. A. (2002). Tehnologii glubokoy pererabotki nefti i gaza. Ufa: Gilem, 672. Available at: https://www.studmed.ru/ ahmetov-sa-tehnologii-glubokoy-pererabotki-nefti-i-gaza_3d291038be0.html

8. Tehnicheskie harakteristiki ustanovki UKM-600 pri pererabotke mazuta ili nefti. Mini NPZ proektirovanie minizavodov po pererabotke nefti. Available at: http://www.mininpz.zx6.ru/Albom2_tkm_500/Albom_tkm_500.htm

9. Abdullin, A. I., Siraev, I. R. (2016). Gidrokreking kak protsess polucheniya dizel'nogo topliva. Vestnik Kazanskogo tehnologicheskogo universiteta, 19 (10), 41-43. Available at: https://cyberleninka.ru/article/n/gidrokreking-kak-protsesspolucheniya-dizelnogo-topliva

10. Mustafaeva, R. M., Salaeva, Z. Ch., Mamedaliev, G. A. (2009). Nekotorye aspekty gidrogenizatsionnoy pererabotki zhidkih produktov piroliza s tsel'yu polucheniya aromaticheskih uglevodorodov. Voprosy himii i himicheskoy tehnologii, 6, 37-42.

11. Mustafin, I. A., Sidorov, G. M., Stankevich, K. E., Bayram-Ali, T. M., Salishev, A. I., Murtazin, E. V., Gantsev, A. V. (2018). Hydrocatalytic processes of heavy oil factions processing with use of perspective nanoscale catalysts. Fundamental research, 7, 22-28. Available at: http://fundamental-research.ru/ru/article/view?id=42201 
12. Morozov, M. A., Akimov, A. S., Fedushchak, T. A., Zhuravkov, S. P., Vlasov, V. A., Sudarev, E. A., Vosmerikov, A. V. (2018). Cracking of Heavy Hydrocarbon Feedstock in the Presence of Cobalt. Kataliz v Promyshlennosti, 18 (2), 33-38. doi: https:// doi.org/10.18412/1816-0387-2018-2-33-38

13. Davletshin, A. R., Obuhova, S. A., Halikov, D. E., Urmancheev, S. F., Vezirov, R. R. (2000). Otsenka vliyaniya rezhimnyh parametrov na gidrodinamicheskie harakteristiki voshodyashchego potoka v reaktsionnoy kamere visbrekinga. Bashkirskiy himicheskiy zhurnal, 7 (5), 64-65.

14. Speight, J. G. (2012). Visbreaking: A technology of the past and the future. Scientia Iranica, 19 (3), 569-573. doi: https://doi.org/ 10.1016/j.scient.2011.12.014

15. Villamarin-Barriga, E., Canacu〈n, J., Londo〉o-Larrea, P., Solłs, H., De La Rosa, A., Saldarriaga, J. F., Montero, C. (2020). Catalytic Cracking of Heavy Crude Oil over Iron-Based Catalyst Obtained from Galvanic Industry Wastes. Catalysts, 10 (7), 736. doi: https://doi.org/10.3390/catal10070736

16. Kurochkin, A. K. (2015). Povyshaem rentabel'nost' mini-NPZ: komplektuem modulem glubokoy pererabotki mazuta. Sfera. Neft' i gaz, 1 (45), 60-66. Available at: https://ru.calameo.com/read/0054049039c1e13a40c81

17. Isakov, A. A., Torosyan, G. O. (2017). Technology for producing liquid fuels through processing carbon-containing wastes and fuel oil. Himicheskaya bezopasnost', 1 (2), 221-226. doi: http://doi.org/10.25514/CHS.2017.2.10996

18. Leonenko, S., Kudryavtsev, S., Glikina, I. (2017). Study of catalytic cracking process of fuel oil to obtain components of motor fuels using aerosol nanocatalysis technology. Adsorption Science \& Technology, 35 (9-10), 878-883. doi: https://doi.org/ $10.1177 / 0263617417722253$

19. Glikina, I., Glikin, M., Kudryavtsev, S. (2017). Study of kinetic parameters for the catalytic cracking process in $Y$ type aerosol catalyst. Eastern-European Journal of Enterprise Technologies, 3 (6 (87)), 4-8. doi: https://doi.org/10.15587/1729-4061.2017.99022

20. Ustanovki i pechi termokrekinga, visbrekinga mazuta. Ustanovka termicheskogo krekinga mazuta TKM-700-2E. Available at: http://nouprom-npz.ru/katalog-produktsii/ustanovki-visbrekinga-mazuta/ 